\title{
Analysis of DNA-damage response to ionizing radiation in serum-shock synchronized human fibroblasts
}

\author{
Samantha Corrà • Riccardo Salvadori • \\ Leonardo Bee • Vito Barbieri • Maddalena Mognato (iD
}

Received: 15 June 2016 / Accepted: 20 April 2017 / Published online: 3 May 2017

(C) The Author(s) 2017. This article is an open access publication

\begin{abstract}
Many aspects of cellular physiology, including cellular response to genotoxic stress, are related to the circadian rhythmicity induced by the molecular clock. The current study investigated if the cellular response to DNA damage is in relation to endogenous expression levels of the PER2 protein, a key component of the molecular regulatory system that confers rhythmicity in mammalian cells. Human normal fibroblasts (CCD-34Lu) were subjected to serum shock to induce circadian oscillations of the PER2 protein and then irradiated with $\gamma$ - rays at times corresponding to the trough and peak expression of the PER2 protein. To better examine cellular response to DNA damage, the experiments performed in this study were carried out in non-proliferating CCD-34Lu fibroblasts in order to maintain the cell and circadian cycles separated while
\end{abstract}

Electronic supplementary material The online version of this article (doi:10.1007/s10565-017-9394-9) contains supplementary material, which is available to authorized users.

S. Corrà $\cdot$ R. Salvadori $\cdot$ L. Bee $\cdot$ M. Mognato $(\bowtie)$

Department of Biology, School of Sciences, University of Padova, via U. Bassi 58 B, 35131 Padova, Italy

e-mail: maddalena.mognato@unipd.it

V. Barbieri

Department of Surgical, Oncological and Gastroenteric Sciences, University of Padova, via Giustiniani 2, Padova, Italy

Present Address:

L. Bee

Menarini Silicon Biosystems, 10355 Science Center Dr \#210, San Diego, CA 92121, USA they were being exposed to genotoxic stress. Study results demonstrated that clonogenic cell survival, double-strand break repair kinetics, and TP53 protein levels were affected in the cells irradiated at the trough than in those irradiated at peak expression of the PER2 protein.

Keywords DNA-damage response - Gamma rays · Circadian clock $\cdot$ Human fibroblasts

$\begin{array}{ll}\text { Abbreviations } \\ \text { DDR } & \text { DNA-damage response } \\ \text { DSB } & \text { Double-strand break } \\ \text { IR } & \text { Ionizing radiation } \\ \text { IRIF } & \text { Ionizing radiation-induced foci }\end{array}$

\section{Introduction}

Mammalian cells possess a cell-autonomous molecular clock which controls the timing of physiological processes and hence the cellular response to external stimuli, including genotoxic stress. All organisms adapt to daily environmental changes by synchronizing multiple molecular, biochemical, physiological, and behavioral processes through daily oscillations in biological processes that are controlled by an endogenous biochemical pacemaker that is termed the circadian clock (Savvidis and Koutsilieris 2012). The master clock is located in the hypothalamic suprachiasmatic nucleus ( $\mathrm{SCN})$, a small brain region containing 10,000-15,000 neurons. 
Core components of the mammalian circadian molecular clock, CLOCK (Circadian Locomotor Output Cycles Kaput) and BMAL1 (brain muscle Arnt-like 1), which are members of the bHLH-PAS transcription factor family, form a heterodimer, which binds to the E-box cisregulatory enhancer elements of their target genes, including Period (PER) and Cryptochromes (CRYs). A negative feedback loop is achieved when the PERs and CRYs form heterocomplexes that translocate back to the nucleus and inhibit their own transcription. In addition to the primary feedback loops, another regulatory one, the "stabilizing loop" (Kwon et al. 2011), is formed by REV-ERB $\alpha$ and ROR $\alpha$, which are orphan nuclear receptors. REV-ERB $\alpha$ competes in the nucleus with ROR $\alpha$ for binding to the ROR-responsive element (RORE) in the Bmall promoter (Gallego and Virshup 2007). While ROR $\alpha$ activates Bmall transcription, REV-ERB $\alpha$ represses it. As a result, the cyclic expression of Bmall is achieved by both the positive and negative regulation of RORs and REV-ERBs. The Period $(\mathrm{Per}$ ) genes are key circadian regulators in mammals that are expressed rhythmically in the SCN as well as in areas outside the SCN. The Per2 gene is an essential component of the mammalian circadian clock and plays a primary role in the human circadian clock since the PER2 $2^{S 62 G}$ mutation causes the familial advanced sleep phase syndrome (Toh et al. 2001; Xu et al. 2005). It is known that genetic ablation of mPER1 and mPER2 function results in a complete loss of circadian rhythm control based on wheel-running activity in mice (Lee 2005). The circadian expression of Per2 is regulated by the transcription factors CLOCK and BMAL1 but also via CREB (cAMP response element binding protein)-dependent transcriptional activation. Among the ATF/CREB family proteins, ATF4 binds to the CRE of the Per 2 promoter in a circadian timedependent manner and periodically activates the transcription of the Per2 gene (Koyanagi et al. 2011).

The circadian system is linked to various physiological processes through clock-controlled genes and the synthesis of products which control DNA synthesis, cell division, and proliferation (Gréchez-Cassiau et al. 2008; Matsuo et al. 2003; Nagoshi et al. 2004; Wood et al. 2006). Clock-related cell cycle progression has evolved to confine DNA replication to the moment of the day when the risk of exposure to environmental and endogenous DNA damaging agents (i.e., UV during the day; reactive oxygen species and other harmful metabolic side products generated during respiratory metabolism) is at its lowest level (Roenneberg and Merrow 2007; Tauber and Kyriacou 2005). DNA repair is a fundamental cellular activity that has evolved to preserve genome stability when environmental conditions or endogenous genotoxic agents endanger an organism's health and life span. Experimental evidence has demonstrated that DNA repair is controlled by the circadian clock and that XPA, the DNA repair protein, is controlled by the circadian clock in the mouse brain, liver, and skin (Gaddameedhi et al. 2011; Kang et al. 2010). It has been found that the activity of nucleotide excision repair (NER) is highest in the afternoon/evening hours and lowest in the night/early morning hours in mice brains (Kang et al. 2009). The circadian clock regulates both DNA sensitivity to UV damage and the efficiency of NER by controlling chromatin condensation (Bee et al. 2015) as well as the repair of 8-oxoG DNA (Manzella et al. 2015). Clock components BMAL1-CLOCK, PER1, PER2, and ROR are involved in controlling the cellular response to genotoxic stress (Gaddameedhi et al. 2011; Kang et al. 2009; Miki et al. 2013).

Epidemiological studies have shown that a disruption in circadian rhythms leads to increased susceptibility to cancer in humans. Indeed, several studies have shown that rotating shift workers have an elevated risk for breast and prostate cancer (Flynn-Evans et al. 2013; Knutsson et al. 2013; Stevens 2005). The International Agency for Research on Cancer (IARC) has, in fact, classified shiftwork involving circadian disruption as probably carcinogenic to humans (Straif et al. 2007). Accumulating evidence suggests that alterations in the DNA-damage response (DDR) pathway induced by circadian rhythm dysregulation (disruption or desynchronicity) could be responsible for tumorigenesis. DDR is a complex pathway consisting in damage sensors, mediators, signal transducers, and effectors that are involved in DNA damage checkpoints and repair, apoptosis, and transcriptional reprogramming. As far as DNA damage is concerned, double-strand breaks (DSBs) represent the most dangerous lesions for genome integrity as they promote genome rearrangements that initiate carcinogenesis or apoptosis. Ataxiatelangiectasia mutated (ATM) is a member of the phosphatidylinositol 3-kinase-related kinase (PIKK) family and is the primary transducer of DSB-induced signaling. In the presence of DSBs, ATM undergoes autophosphorylation which promotes its activation to phosphorylate proteins that control signal transduction, cell cycle progression, and DNA repair. Following DNA damage, 
the ATM kinase phosphorylates the $\mathrm{C}^{\prime}$ terminus of MDM2 and the BOX-I of p53, switching MDM2 from binding the $\mathrm{p} 53$ protein and promoting $\mathrm{p} 53$ stabilization and activation (Karakostis et al. 2016). Following ATMmediated activation, the TP53 tumor suppressor exerts its transcription regulatory activity mostly through direct binding to the regulatory sequences of its target genes. Among these, several genes belonging to the p53 pathway are under the control of the circadian clock, such as c-MYC, CDKN1A (encoding cyclin-dependent kinase inhibitor P21), and GADD45A. The $c-M Y C$ oncogene is a first-order clock-controlled gene with a role in cellular proliferation (Fu et al. 2002). CDKN1A is a second-order clock-controlled gene, negatively regulated by REV-ERB $\alpha$, which is involved in $\mathrm{G}_{1} / \mathrm{S}$ and intraS-checkpoint regulation but also in base excision repair (Gréchez-Cassiau et al. 2008). The cell cycle gene $G A D D 45 A$, whose transcript levels are increased following stressful growth arrest conditions, is under the indirect circadian control of the essential Per2 clock gene (Canaple et al. 2003). Although several studies have investigated the relationships between the circadian clock, cell cycle progression and apoptosis induction (Fu et al. 2002; Gery et al. 2006; Matsuo et al. 2003; Kowalska et al. 2013), the mechanisms underlying the circadian regulation of DDR pathways have not been completely elucidated.

The current study set out to investigate if cellular response to DNA damage is affected by the circadian phase at which cells are stressed. Human primary fibroblasts were thus irradiated at circadian times corresponding to the trough and the peak of the PER2 protein expression, often used as a marker of circadian time and considered a circadian readout in the context of this study. Clonogenic cell survival, DSB repair kinetics, and TP53 protein expression were analyzed as the endpoints of the DNA-damage response. The experiments were performed in non-proliferating human lung fibroblasts in order to separate the cell cycle from the circadian clock.

\section{Materials and methods}

Cell cultures and circadian rhythm induction

Normal human neonatal lung fibroblasts CCD-34Lu (ATCC N. CRL-1491'TM) were grown in high glucose (4.5 g/l) Dulbecco's modified Eagle's medium
(DMEM) containing GlutaMAX (Gibco, Life Technologies), supplemented with $10 \%$ heat-inactivated fetal calf serum (FCS, Biochrom KG, Seromed), HEPES $20 \mathrm{mM}$ (Sigma-Aldrich), and 1\% MEM non-essential amino acids (Gibco, Life Technologies). At the time the experiments were carried out, the cells were at 13 to 16 population doublings and were actively proliferating, as confirmed by flow cytometry analysis of DNA content (Supplementary Fig. S1). Cultures of non-proliferating CCD-34Lu were obtained by seeding cells $\left(1 \times 10^{6}\right)$ in $100 \times 20 \mathrm{~mm}$ Petri dishes in a culture medium supplemented with $10 \%$ FCS until cells reached confluence ( 8 days); they were then shifted to a medium containing 50\% horse serum (Life Technologies) and incubated for $2 \mathrm{~h}$ at $37{ }^{\circ} \mathrm{C}$. At the end of the incubation period, the cells were incubated in fresh serum-free medium during the entire 44-h post-serum-shock treatment period (Fig. 1).

\section{Cell irradiation}

Cells were irradiated at the Department of Oncological and Surgical Sciences of Padova University with a ${ }^{137} \mathrm{Cs}$ source (dose rate of $2.8 \mathrm{~Gy} / \mathrm{min}$ ) at trough and peak PER2 protein expression. Control cells were subjected to all of the same experimental conditions as the irradiated one, except for irradiation.

\section{Clonogenic assay}

After irradiation, the cells were harvested by trypsinization and counted by trypan blue dye exclusion. Five hundred viable CCD-34Lu cells were seeded together with feeder layer IMR90 cells $\left(15 \times 10^{5}\right.$ cells/plate $)$ in complete medium supplemented with $15 \%$ FCS, as described elsewhere (Fede et al. 2012). Four replicate dishes were prepared for each experimental point, and the cells were incubated for 12 days to allow the colonies to develop. The colonies were stained with $0.4 \%$ crystal violet before counting, and only colonies containing more than 50 cells were scored as survivors. Cell survival was calculated as the percentage of cloning efficiency (CE) of the irradiated cells over that of non-irradiated control cells.

\section{FACS analyses}

The distribution of cells was assessed by flow cytometry analysis of cellular DNA content, as described 
Fig. 1 The experimental procedure to induce circadian rhythmicity in non-proliferating human fibroblasts CCD-34Lu

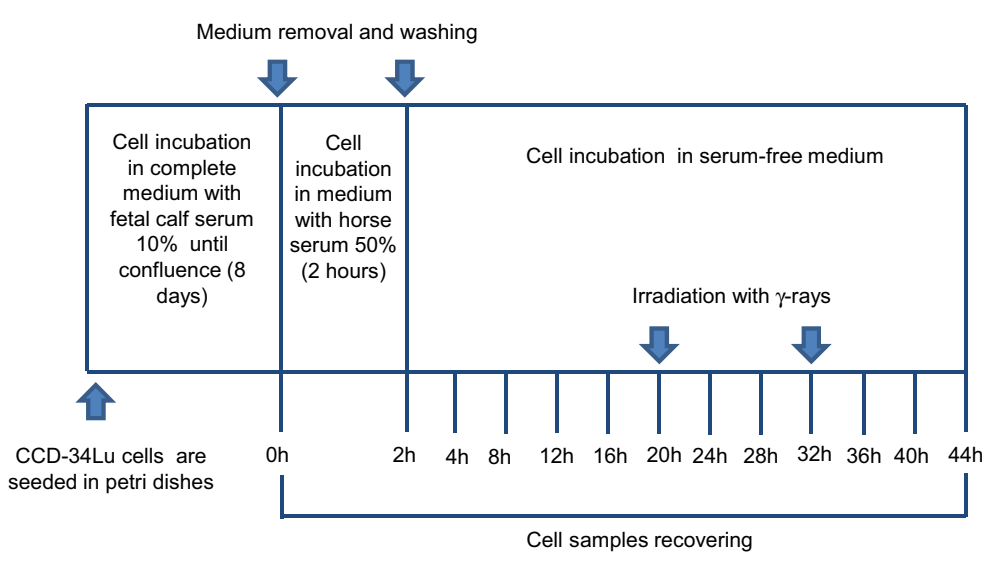

Total RNA isolation and qRT-PCR

elsewhere (Canova et al. 2005). The cells were trypsinized, counted, and seeded at low density in new dishes in completely fresh medium. Three, 24, 30, and $48 \mathrm{~h}$ following re-plating, the cells were recovered and analyzed after they were stained with propidium iodide (PI) $(50 \mu \mathrm{g} / \mu \mathrm{L})$ and RNase $(100 \mu \mathrm{g} / \mathrm{ml})$. The samples were analyzed using a BD FACSCanto ${ }^{\text {TM }}$ II flow cytometer (BD Biosciences); data from $10 \times 10^{3}$ cells/ sample were collected for acquisition and cell cycle distribution analysis using CellQuest (version 3.0, BD Biosciences) and ModFit LT 3.0 software (BD Biosciences), respectively.

\section{Transfection with siRNAs}

Confluent non-proliferating CCD-34Lu cells were transfected with $32 \mathrm{nM}$ of Stealth RNAi ${ }^{\mathrm{TM}}$ siRNA anti-PER2 (Life Technologies) or siRNA negative control (Life Technologies) using RNAiMAX (Life Technologies). The siRNA HSS113093 (Supplementary Fig. S2) resulted as the most efficient in PER2 downregulation and was chosen for siRNA-transfection experiments. Transfections were performed in DMEM medium without antibiotics supplemented with $0.1 \%$ FBS, and after 3 days, the medium was diluted 1:1 with fresh DMEM$0.1 \%$ FBS and cells were incubated for an additional 3 days in the presence of $16 \mathrm{nM}$ siRNA. CCD-34Lu cells were then transfected a second time with $32 \mathrm{nM}$ of siRNA in DMEM-0.1\% FBS (Franzolin et al. 2013). After $24 \mathrm{~h}$, the cell medium was exchanged with DMEM containing $50 \%$ horse serum, incubated for $2 \mathrm{~h}$ at $37^{\circ} \mathrm{C}$, washed twice, and incubated in the previous medium containing siRNAs during the whole 44-h period after serum shock.
At the end of incubation periods after serum-shock synchronization, total RNA was isolated from CCD-34Lu cells using TRIzol® Reagent (Invitrogen, CA) following the manufacturer's instructions. Total RNA quantification and RNA integrity evaluation were performed using the ND-1000 spectrophotometer (Nanodrop, Wilmington, DE) and the Agilent Bioanalyzer 2100, as described elsewhere (Girardi et al. 2012). One microgram of total RNA was retro-transcribed with ImProm-II Reverse Transcription System (Promega). Quantitative real-time PCR (qRT-PCR) was performed with the GoTaqqPCR Master Mix (Promega) and gene-specific primers for PER2, BMAL1, TP53, CDKN1A, GADD45A, and $c$ $M Y C$ genes and for GAPDH as reference. qRT-PCR reactions were always performed in quadruplicates. The gene expression levels were calculated using the comparative delta threshold cycle (CT) method $\left(2^{-\Delta C T}\right)$ implemented in the 7500 Real-Time PCR System software (Livak and Schmittgen 2001).

Immunofluorescence staining

Immunofluorescence detection of $\gamma-\mathrm{H} 2 \mathrm{AX}$ and 53BP1 foci was used to detect DNA-damage induction and repair. The cells $\left(0.4 \times 10^{6}\right)$ were seeded on Petri dishes $(60 \times 15 \mathrm{~mm})$ containing coverslips and were treated for circadian clock synchronization. They were then irradiated at trough and peak PER2 expression and cultured at $37{ }^{\circ} \mathrm{C}$ in fresh serum-free medium for different repair times $(0.5,2,6$, and $24 \mathrm{~h})$. At each time point, the nonirradiated and irradiated cells were rinsed once with cold PBS and fixed with a $4 \%$ solution of formaldehyde 
(Sigma-Aldrich) at $37{ }^{\circ} \mathrm{C}$ for $15 \mathrm{~min}$. The cells were washed three times for $5 \mathrm{~min}$ in PBS, permeabilized in $0.2 \%$ Triton X-100-PBS and blocked in $10 \%$ goat serum-PBS for $1 \mathrm{~h}$ at room temperature. The cells were then incubated for $2 \mathrm{~h}$ at room temperature with primary antibodies anti- $\gamma-\mathrm{H} 2 \mathrm{AX}$ (Ser139) Clone JBW301 (Millipore, lot. no. DAM1493341, 1:100, or Abcam, ab11174, 1:100) or anti-53BP1 (Bethyl Laboratories, lot. no. A300-273A-4, 1:100) and then washed three times in PBS and once in PBS $+0.1 \%$ Triton X-100. The cells were then incubated at room temperature for $1 \mathrm{~h}$ with secondary antibodies Alexa Fluor® 488 goat anti-mouse and Alexa Fluor ${ }^{\circledR} 594$ donkey anti-rabbit (Life Technologies, 1:350) and washed, as described elsewhere. Cells were washed and counterstained with $2 \mu \mathrm{g} / \mathrm{ml}$ DAPI (4',6-diamidino-2-phenylindole) in antifade solution (Vectashield, Vector Laboratories), and cover glass slips were mounted. Images of $\gamma$ H2AX and 53BP1 foci were captured using a Leica TCS SP5 confocal microscope (Leica Microsystems) with a $63 \times$ oil immersion objective. All the images were acquired under the same conditions of laser intensity, PMC voltage, pinhole aperture, and optical slice $(0.5 \mu \mathrm{m})$ and processed by Adobe Photoshop 8.0 software (Adobe). For each experimental point, foci were scored by eye from 300-500 nuclei.

Subcellular fractionation and SDS PAGE

Cellular extracts were prepared from serumsynchronized cells 0,5 , and $24 \mathrm{~h}$ after irradiation and in non-irradiated cells. Nuclear extraction of proteins was performed using the CelLytic ${ }^{\mathrm{TM}}$ NuCLEARTM ${ }^{\mathrm{TM}}$ traction Kit (Sigma-Aldrich), following the manufacturer's instructions. Briefly, cells $\left(2.5 \times 10^{6}\right)$ were suspended in Lysis Buffer $1 \times$, containing DTT and protease inhibitors, incubated on ice $15 \mathrm{~min}$ allowing cells to swell. Then a $10 \%$ IGEPAL CA-630 solution to a final concentration of $0.6 \%$ was added to the swollen cells. Cells were vortexed and centrifuged at $10.000 \times g$ for $30 \mathrm{~s}$, and the cytosolic fraction was recovered. The nuclei pellet was resuspended in Extraction Buffer containing DTT and protease inhibitors, vortexed for $30 \mathrm{~min}$, and centrifuged at $21.000 \times \mathrm{g}$ for $5 \mathrm{~min}$, and supernatant containing the nuclear fraction was collected. Ten micrograms of nuclear fraction were separated on $10 \%$ SDS-polyacrylamide gels and transferred to nitrocellulose membranes (Hybond-C Extra; Amersham, GE Healthcare). Membranes were then probed with primary antibodies anti-PER2 (H-90, sc25363, Santa Cruz, 1:200), anti-p53 (Ser20) (1C12, Cell Signaling, 1:100), anti-phospho-p53 (Ser15) (16G8, Cell Signaling, 1:100), and anti-GAPDH (Millipore, 1:5000) and then incubated with Amersham ECL horseradish peroxidase-conjugated secondary antibodies (GE Healthcare, 1:40.000). The resulting immunoreactive bands were detected using enhanced chemiluminescent HRP substrate (Millipore). The bands' intensities were quantified with ImageJ software and normalized utilizing GAPDH.

Statistical analysis

All data are expressed as the means \pm standard deviation (SD) of at least three independent replicate experiments. Student's $t$ test was used to analyze differences between two groups of clonogenic assay. Comparisons between multiple groups of ionizing radiation-induced foci were made using two-way analysis of variance (ANOVA) and Tukey's post hoc test. Values of $p<0.1$ were considered to be statistically significant.

\section{Results}

Induction of circadian rhythm in human fibroblast cultures

Unlike the Drosophila and zebrafish model organisms in which the peripheral clock can be entrained directly by light (Ceriani et al. 1999; Whitmore et al. 2000), one or more blood-borne factors are required in mammals to stimulate signal transduction pathways that influence the molecular oscillators in peripheral cells. In vitro, brief treatment of cultured rat1 fibroblasts with various compounds (serum, forskolin, cAMP or dexamethasone, etc.) induces rhythmic expression of clock genes (Per 1, Per 2, Cry l) and the circadian transcription factors (REV-ERB $\alpha, \mathrm{DBP}$, and TEF) for two to three consecutive daily oscillations, with an average period of $22.5 \mathrm{~h}$ (Allen et al. 2001; Balsalobre et al. 1998). Circadian rhythm is successfully induced by serum shock and cAMP analogs in cultured human mesenchymal stem cells (Huang et al. 2009).

The experiments performed in this study were carried out in non-proliferating CCD-34Lu fibroblasts in order to maintain the cells and circadian cycles separated while they were being exposed to genotoxic stress. 
The cells were grown in normal culture conditions until they reached confluence $\left(G_{1}\right.$ phase), which was confirmed by flow cytometric analyses (Supplementary Fig. S1). They were then incubated for $2 \mathrm{~h}$ in fresh medium containing horse serum $(50 \%)$. At the end of serum shock, a serum-free medium was used and the cells were incubated for $44 \mathrm{~h}$ (Supplementary Fig. S2). To verify the rhythmic expression of clock genes, we analyzed the expression of PER1, PER2, and BMAL1 mRNAs at the beginning and at the end of serum shock and every $4 \mathrm{~h}$ for a $44-\mathrm{h}$ interval. Both PER 1 and PER2 transcripts confirmed a circadian expression within approximately a 24-h period, with a trough at $12 \mathrm{~h}$ and a peak at $24 \mathrm{~h}$ after serum shock, although PER2 induction was more evident (Fig. 2a). BMAL1 transcript was, as expected, in anti-phase with PER1 and PER2, with the trough at $24 \mathrm{~h}$ after serum shock and two peaks at 12 and $36 \mathrm{~h}$, respectively, after serum shock. We then analyzed the expression level of PER2, the key mammalian circadian clock protein, which showed two peaks of induction, at 4-8 and 28-36 h after serum shock, and a trough one at 12-20 h after serum shock (Fig. 2b, c), confirming a circadian oscillation of about $24 \mathrm{~h}$. To evaluate the role of PER2 in the circadian phase of our system, we performed experiments of PER 2 silencing in CCD-34Lu cells subjected to serum shock. We first analyzed the expression of PER2 transcript in cells transfected with siPER2 or siCTRL to verify the effect of silencing throughout the 0-44-h period after serum shock, and then we analyzed the expression of PER1 and BMAL1 transcripts by qRT-PCR (Fig. 3). Our results show that the PER1 peak expression (at 2 and $24 \mathrm{~h}$ after serum shock) was reduced after $P E R 2$ knockdown, whereas BMAL1 expression level maintained on the whole a circadian rhythmicity, within approximately a 24-h period even though its peak expression was $4 \mathrm{~h}$ shifted in siPER 2 cells ( $16 \mathrm{~h}$ instead of $12 \mathrm{~h}$ after serum shock).

Clonogenic survival in cells irradiated at trough and peak PER2 protein expression

We investigated the role of PER2 expression level in regulating the cellular response to DNA damage by first analyzing cell survival in relation to the circadian phase during which cells were exposed to ionizing radiation (IR). To this aim, we selected circadian times corresponding to the trough and the peak of PER2 protein expression, as a marker of circadian phase, in order to administer genotoxic stress at those times. In accordance with previous results, PER2 protein was maximally induced at 28-36 h after serum shock and minimally expressed between 12 and $20 \mathrm{~h}$ after serum shock (Bee et al. 2015). We thus chose two circadian times separated by a 12-h interval (i.e., 20 and $32 \mathrm{~h}$ ) as respectively the trough and the peak of PER2 protein expression. We assessed cell survival after irradiation, performed at the trough and the peak of PER2 protein expression, by determining the cloning efficiency (CE) of irradiated and non-irradiated control cells (CTRs) that were subjected to the same treatments except irradiation. As previously reported, cells irradiated at the peak of PER2 expression displayed cloning efficiency values that were typical of this cell line (Bee et al. 2013). The cells irradiated at trough PER2 expression were less able in general to form colonies with respect to the cells irradiated at its peak (Fig. 4a) and showed decreased cell survival at all doses (Fig. 4b; $p<0.001$ for $0.5 \mathrm{~Gy}$; $p<0.01$ for $1 \mathrm{~Gy} ; p<0.05$ for $2 \mathrm{~Gy}, t$ test). As the nonirradiated control cells showed similar CE values at both circadian times, this would seem to indicate that their ability to form colonies did not change as a function of the time the cells were kept in serum-free medium. Cell cycle analysis was also performed on the non-irradiated cells recovered at PER2 protein trough and peak, replated at low density $\left(25 \times 10^{4}\right.$ cells $\left./ \mathrm{cm}^{2}\right)$ in fresh medium supplemented with serum and analyzed 3, 24, 30 , and $48 \mathrm{~h}$ later. Re-plating in fresh complete medium stimulated cell growth in both cell groups, and despite the fact that $24 \mathrm{~h}$ after re-plating the $\mathrm{S}-\mathrm{G}_{2}$ fraction was higher in the cells harvested at the peak than at the trough of PER2 expression, $30 \mathrm{~h}$ after re-plating, the $\mathrm{S}-\mathrm{G}_{2}$ fraction was similar in the two cell groups $(\sim 34 \%$, Fig. 4d). Cell growth analysis was performed also in serum-shocked CCD-34Lu cells irradiated with 1 and 5 Gy at the peak and trough of PER2, harvested, replated at low density, and recovered at 24,30 , and $48 \mathrm{~h}$ after irradiation (supplementary Fig. 3). At $24 \mathrm{~h}$ after replating, the $\mathrm{S}-\mathrm{G}_{2}$ fraction in 1-Gy-irradiated cells was similar in both cell groups $(\sim 25 \%)$, whereas at $30 \mathrm{~h}$ after re-plating, the $\mathrm{S}-\mathrm{G}_{2}$ fraction was higher in cells irradiated at the trough than at the peak of PER2 expression (40 vs. $17 \%$, respectively); at $48 \mathrm{~h}$ after re-plating, most of the cells were $\mathrm{G}_{1}$-arrested in both cell groups but the S$\mathrm{G}_{2}$ fraction was still higher in cells irradiated at PER2 trough (11 vs. 3\%). These findings suggest that the circadian effect related to PER2 expression manifests on the proliferation ability of both isolating cells (i.e., 
a

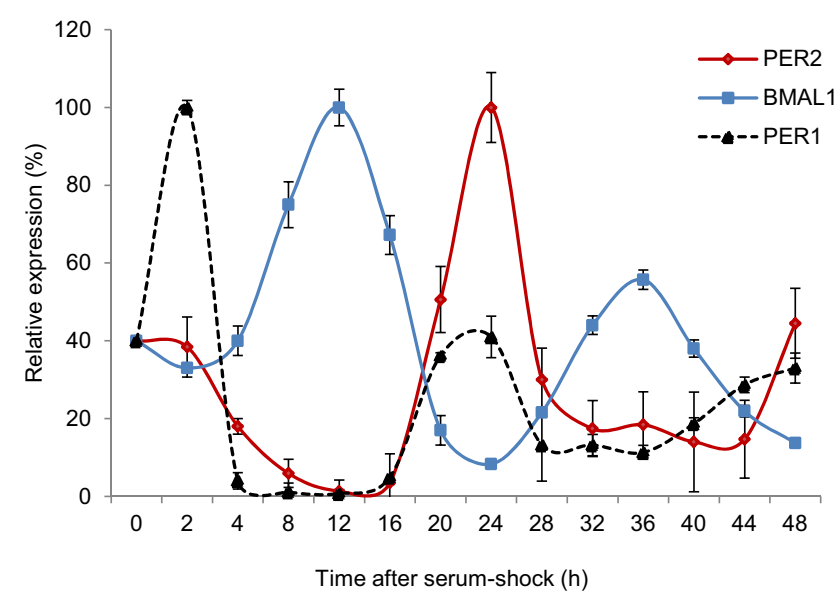

Fig. 2 Induction of circadian rhythm in serum-shocked human CCD-34Lu fibroblasts. a Expression of PER1, PER2, and BMAL1 transcripts obtained using qRT-PCR analysis at the indicated time points beginning at serum shock $(0 \mathrm{~h})$. The values are normalized with $G A P D H$ mRNA as an internal control and plotted as

during clonogenic assay) and cells growing in culture. In 5-Gy-irradiated cells, no evident differences of cell growth emerged from the two groups since most of the cells was in $\mathrm{G}_{1}$-phase starting from $24 \mathrm{~h}$ after re-plating in accordance with previous data (Bee et al. 2013).

Analysis of DSB repair kinetics in cells irradiated at trough and peak PER2 protein expression

In response to DSBs, the phosphorylation of histone $\mathrm{H} 2 \mathrm{AX}(\gamma-\mathrm{H} 2 \mathrm{AX})$ is one of the earliest ATMdependent responses to IR, which is necessary for the accumulation of numerous essential proteins in irradiation-induced foci (IRIF) and playing a critical role in recruiting DNA-damage signaling and repair proteins at DSB sites (Celeste et al. 2003). Among these, the tumor suppressor p53-binding protein 1 (53BP1) becomes hyperphosphorylated after irradiation and colocalizes with phosphorylated $\mathrm{H} 2 \mathrm{AX}$ in megabase regions surrounding the sites of DNA strand breaks (Rappold et al. 2001; Schultz et al. 2000), and the time course of 53BP1 foci formation/disappearance is similar to that of $\gamma-\mathrm{H} 2 \mathrm{AX}$ foci. Since the number of foci is correlated with the number of DNA DSBs (Sharma et al. 2012), we monitored the kinetics of DSBs by in situ immunofluorescence of IRIF of $\gamma-\mathrm{H} 2 \mathrm{AX}$ and 53BP1 proteins. The cells were irradiated at the trough and peak PER2 protein expression and then fixed at different time points b

Time after serum shock $(h)$

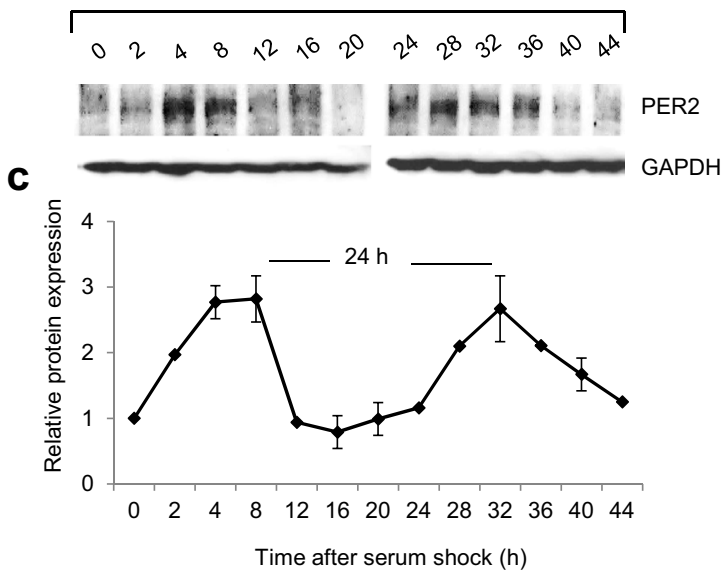

percentages (means \pm SD). b Representative western blot of PER2 protein at the same time points after serum shock and its quantification expressed in the fold-change (FC) relative to GAPDH protein as loading control (c)

$(0.5,2,6,24 \mathrm{~h})$ after irradiation. The quantification of foci per nucleus showed that DSB resolution proceeded with similar kinetics in both cell groups, although cells irradiated when PER 2 protein was minimally expressed generally showed $\sim 2-4$ more IRIF/nucleus than cells irradiated at peak PER2 expression at all time points after IR (Fig. 5a). By categorizing the cells as having 0 $4,5-9,10-15$, and $>15$ foci/nucleus, it nevertheless emerged that a significant fraction of the cells irradiated at the trough PER2 expression retained more IRIF/ nucleus with respect to the cells irradiated at its peak. In particular, for time 6 and $24 \mathrm{~h}$, the resulting interactions were significant with two-way ANOVA test (respectively $p=8.17 \mathrm{e}^{-10}$ and $p=1.61 \mathrm{e}-10$ ). Then, using Tukey HSD test for ANOVA, we found a significant difference for the categorization $10-15$ at $6 \mathrm{~h}(p=0.024)$ and for the categorizations 5-9 $(p=0.025)$ and $0-4$ at $24 \mathrm{~h}$ after irradiation $(p=0.077)$ (respectively at $6 \mathrm{~h}$ and at $24 \mathrm{~h}$ after IR, Fig. $5 \mathrm{c}$ ).

Analysis of TP53 expression in serum-shocked CCD-34Lu cells

Since the TP53 gene is pivotal in the DDR process, we analyzed the expression of its transcript in serumshocked cells irradiated with 5 Gy at the peak and the trough of PER 2 protein expression and analyzed them 0 , 5, and $24 \mathrm{~h}$ after irradiation (Fig. 6a). The expression 
Fig. 3 Role of PER2 in the circadian phase of serum-shock synchronized human fibroblasts CCD-34Lu. Relative expression measured by qRT-PCR analysis of PER2(a), PER1 (b), and $B M A L 1$ (c) transcripts in cells transfected with siPER2 and siCTRL and for comparison in untransfected control cells (CTRL) analyzed at the indicated time points beginning at serum shock $(0 \mathrm{~h})$. The values (means $\pm \mathrm{SD}$ ) are normalized with $G A P D H$ mRNA as an internal control and plotted as fold-change
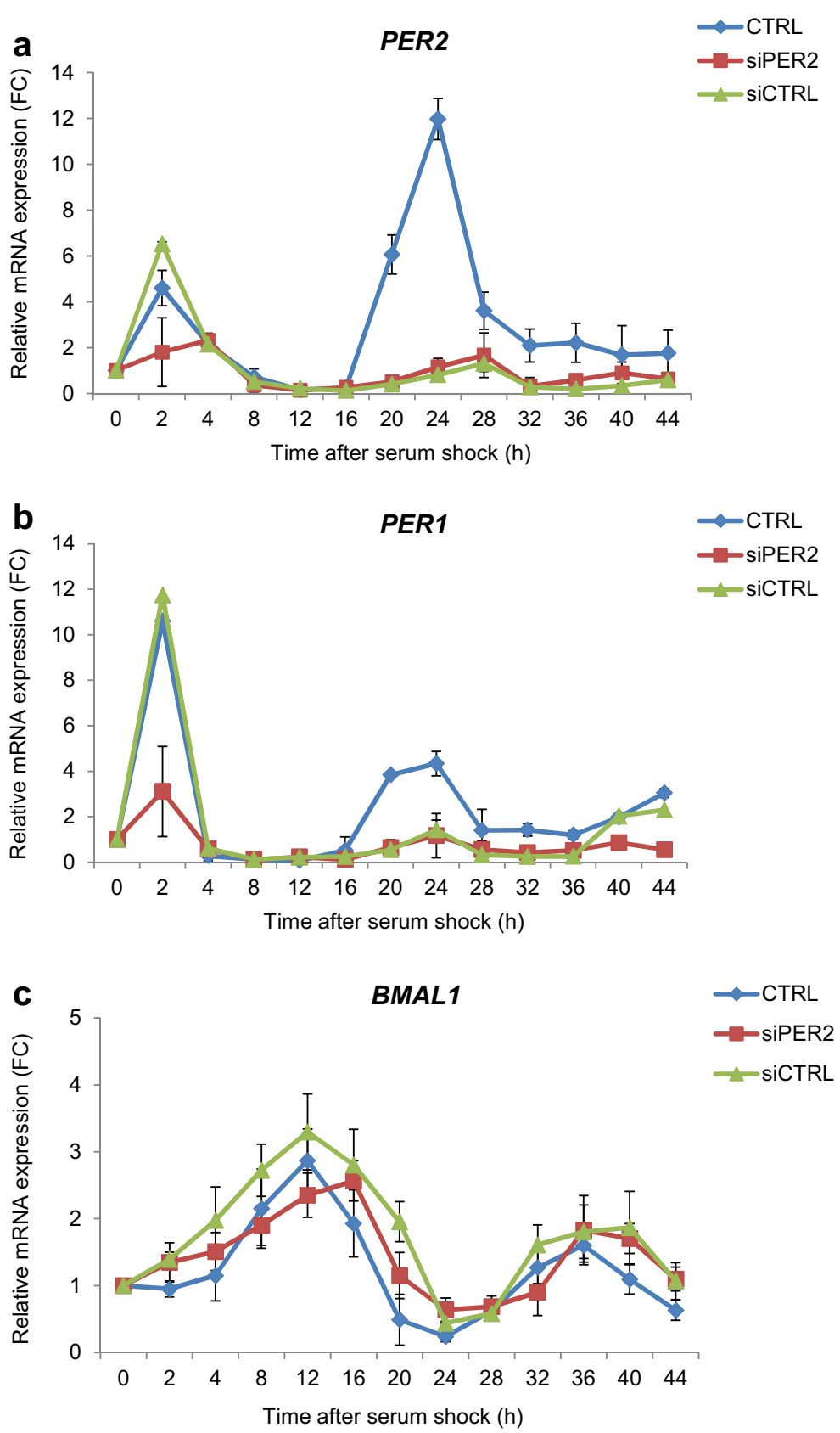

level of TP53 mRNA was downregulated at $5 \mathrm{~h}$ after IR in both cell groups, and at $24 \mathrm{~h}$ after, IR returned to control value $(\sim 1)$ in the cells that were irradiated at the peak of PER2 protein expression. To verify whether TP53 protein was affected in the cells irradiated at different circadian times, we used western blot to assess the levels of nuclear TP53 protein in the cells irradiated at the peak and the trough of PER2 expression and harvested very early $(0 \mathrm{~h}), 5$, and $24 \mathrm{~h}$ after irradiation
(Fig. 6b, c). The results showed that TP53 protein accumulated in the cells irradiated at the peak of PER2 protein expression, in particular at 0 and $24 \mathrm{~h}$ after IR, whereas it was poorly detectable in the cells irradiated at the trough of PER2 expression. To further analyze TP53 behavior, we also assessed the nuclear phosphorylated TP53(Ser15) levels at the same times after irradiation. Phospho-p53 was detectable very early after irradiation in the cells irradiated at the peak but not at the trough 

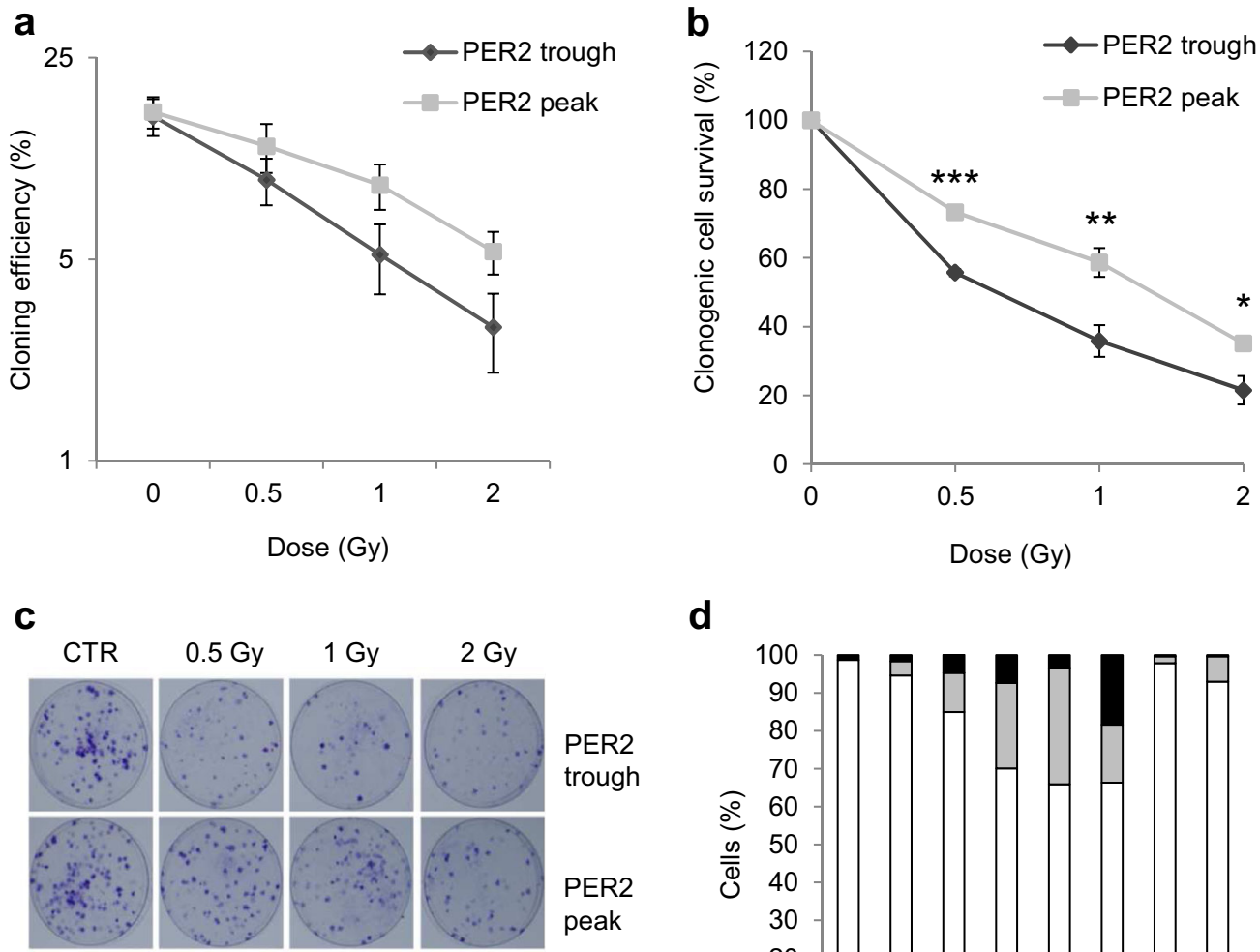

Fig. 4 Clonogenic cell survival of serum-shocked $\gamma$-irradiated human CCD-34Lu fibroblasts. a The cloning efficiency (CE) of serum-shocked non-irradiated ( 0 Gy) cells and of cells irradiated with 0.5-1-2 Gy at the trough and the peak of PER2 protein expression, as a marker of the circadian clock. b Cell survival rate was calculated as the percentage of $\mathrm{CE}$ of irradiated cells with respect to that of non-irradiated control cells treated with serum shock and analyzed at the same circadian times. Data refer to

PER2 expression and very poorly detectable at later time points after irradiation in either cell group.

Expression analysis of p53-related genes in cells irradiated at trough and peak PER2 expression

We evaluated whether the activity of TP53 as transcriptional regulator was affected in relation to PER2 expression by analyzing the expression level of the p53-related genes CDKN1A (p21), c-MYC, and GADD45A in CCD34Lu cells irradiated at trough and peak PER2 expression. At $5 \mathrm{~h}$ after irradiation, the transcription of $C D K N 1 A$ was five- to sixfold induced in both cell

d

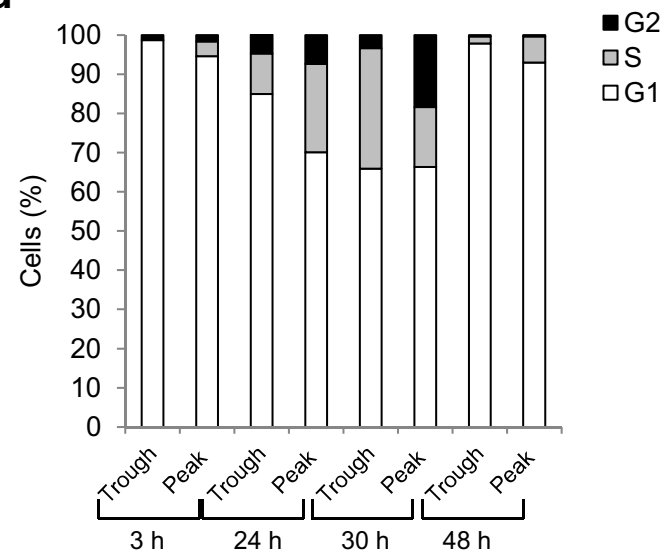

means $\pm \mathrm{SD}$ of independent experiments $(* * * p<0.001$, $* * p<0.01, * p<0.05 ; t$ test). c Colony formation in representative dishes of non-irradiated (CTR) and irradiated cells recovered at the trough and the peak of PER2 expression. $\mathbf{d}$ Cell cycle analyses in cells recovered at the trough and the peak of PER2 protein expression, re-plated at low density, and analyzed 3, 24, 30, and $48 \mathrm{~h}$ later. Data were collected from 10.000 cells/sample using a BD FACSCanto $^{\mathrm{TM}}$ II flow cytometer

groups and then decreased at $24 \mathrm{~h}$ after irradiation, being approximately twofold over the control in both cell groups (Fig. 7). $c-M Y C$ showed a twofold induction at $5 \mathrm{~h}$ after irradiation in cells irradiated at peak but not at trough of PER2; at $24 \mathrm{~h}$ after irradiation, its level was similar to that of control in both cell groups. GADD45A was more induced in cells irradiated at PER2 peak than trough (fourfold vs. twofold, respectively) at $5 \mathrm{~h}$ after irradiation; at $24 \mathrm{~h}$ after irradiation, its expression level decreased and was similar in both groups (approximately threefold over control). The expression level of PER2 gene was unaffected in the two cell groups at both time points after irradiation. 
a

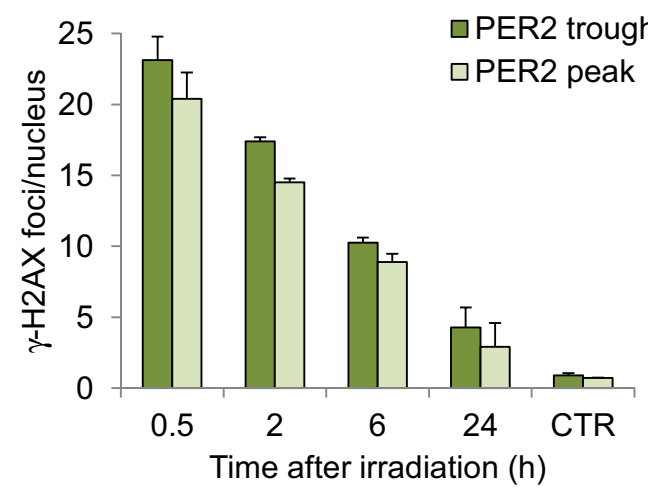

b

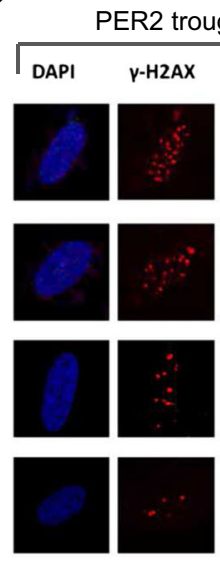

C

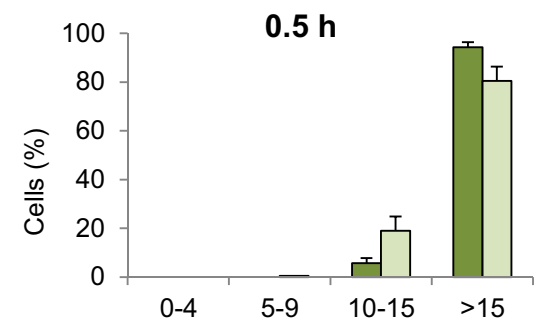

$6 \mathrm{~h}$

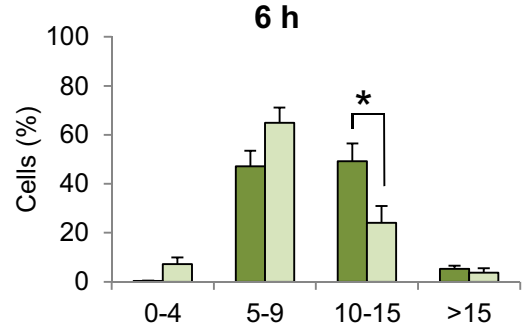

Figure 5 The kinetics of ionizing radiation-induced foci (IRIF) in serum-shocked $\gamma$-irradiated human CCD-34Lu fibroblasts. The mean number of $\gamma$-H2AX foci and 53BP1 foci (a) after irradiation administered at the trough and the peak of PER2 protein expression. b Representative immunofluorescence of $\gamma-\mathrm{H} 2 \mathrm{AX}$ and 53BP1 foci in nuclei stained with DAPI at 0.5, 2 ,
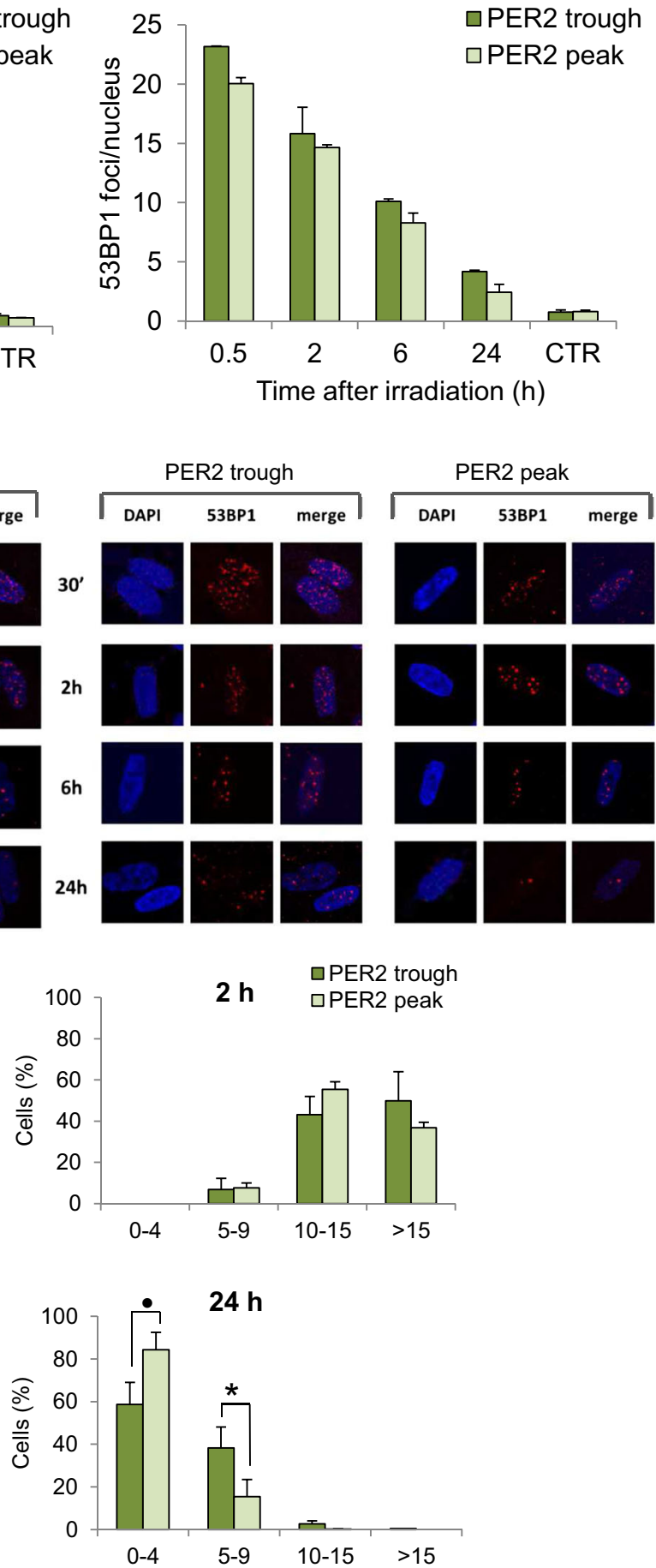

6 , and $24 \mathrm{~h}$ after irradiation. $\mathbf{c}$ Cells were categorized as having 0 $4,5-9,10-15$, and $>15$ of $\gamma-\mathrm{H} 2 \mathrm{AX}$ and 53BP1 foci/nucleus. Data are means $\pm \mathrm{SD}$ from independent experiments, each with at least 200 nuclei/time points, carried out in cells irradiated at the trough and the peak of PER2 protein expression $\left({ }^{\circ} p<0.1\right.$, ${ }^{*} p<0.05$; ANOVA test) 
a

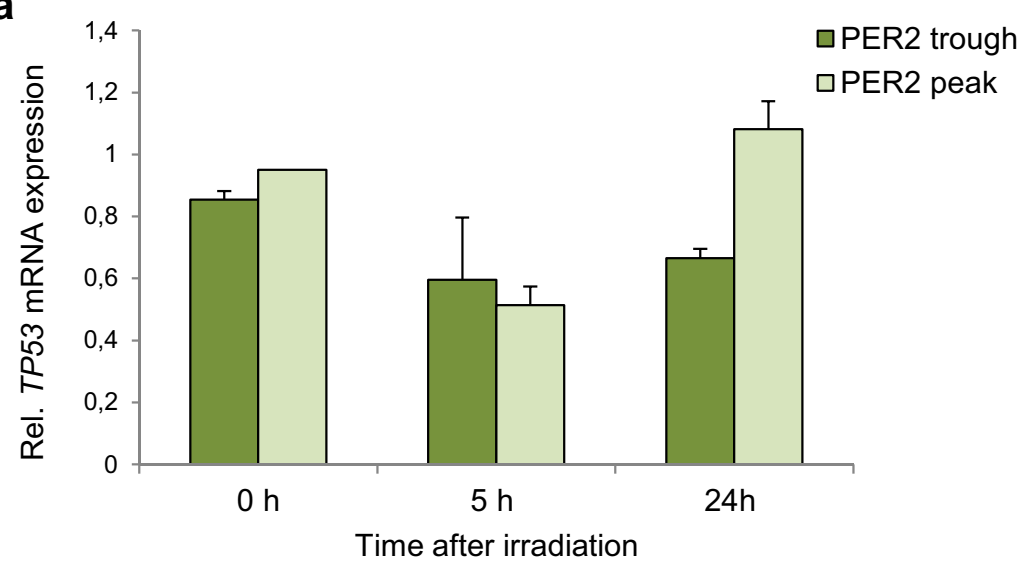

b

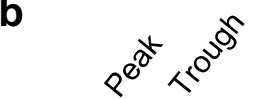<smiles>[CH]C=[Co]</smiles>

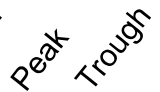

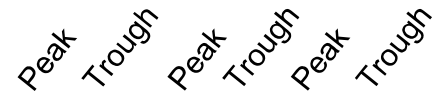

TP53
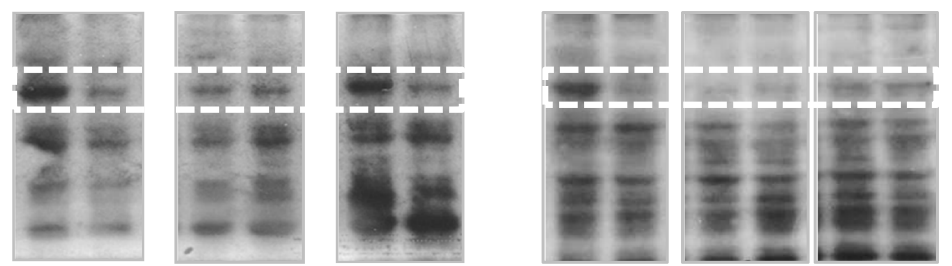

TP53(phospho-Ser15)

$\mathrm{Oh}$ $5 \mathrm{~h}$ $24 \mathrm{~h}$

GAPDH
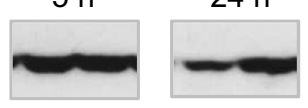

$\mathrm{Oh}$

$5 \mathrm{~h}$

$24 \mathrm{~h}$

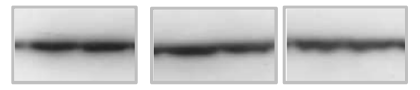

GAPDH
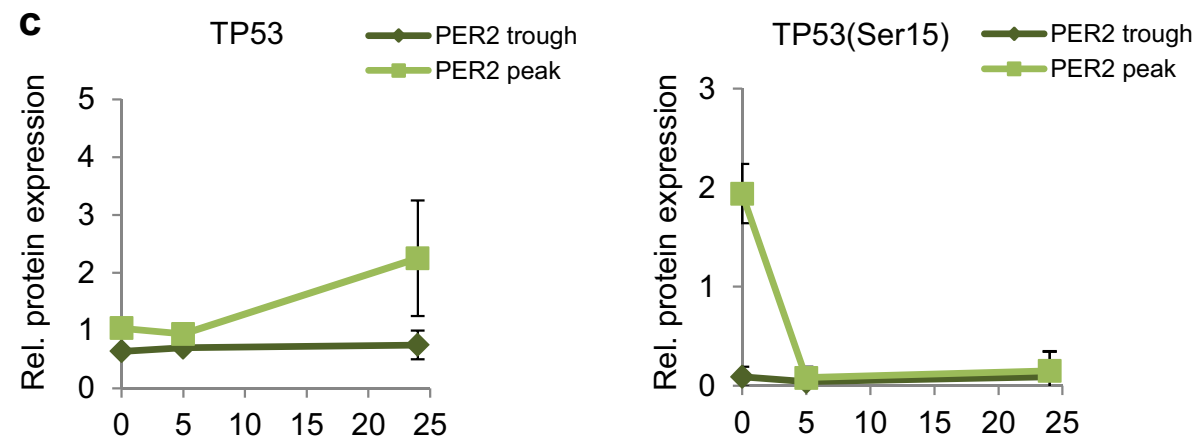

Time after irradiation (h)

Fig. 6 Analysis of TP53 expression in serum-shocked CCD$34 \mathrm{Lu}$ cells irradiated with $\gamma$-rays at circadian times corresponding to the peak and the trough of PER 2 protein expression. a The relative expression of the TP53 transcript was measured at 0,5 , and $24 \mathrm{~h}$ after irradiation with $\gamma$ rays ( $5 \mathrm{~Gy}$ ); data are means $\pm \mathrm{SD}$ expressed as fold-change of irradiated vs. non-irradiated cells. b TP53 protein accumulation in nuclear extracts of cells irradiated

\section{Time after irradiation $(\mathrm{h})$}

with 5 Gy at the trough and the peak of PER2 protein expression and harvested at 0,5 , and $24 \mathrm{~h}$ after irradiation. Representative western blot of TP53 and phosphorylated-TP53(Ser15) proteins and GAPDH as loading control. c Relative expression of TP53 and phosphorylated-TP53(Ser15) proteins; the bands' intensities were quantified with ImageJ software and normalized using GAPDH 

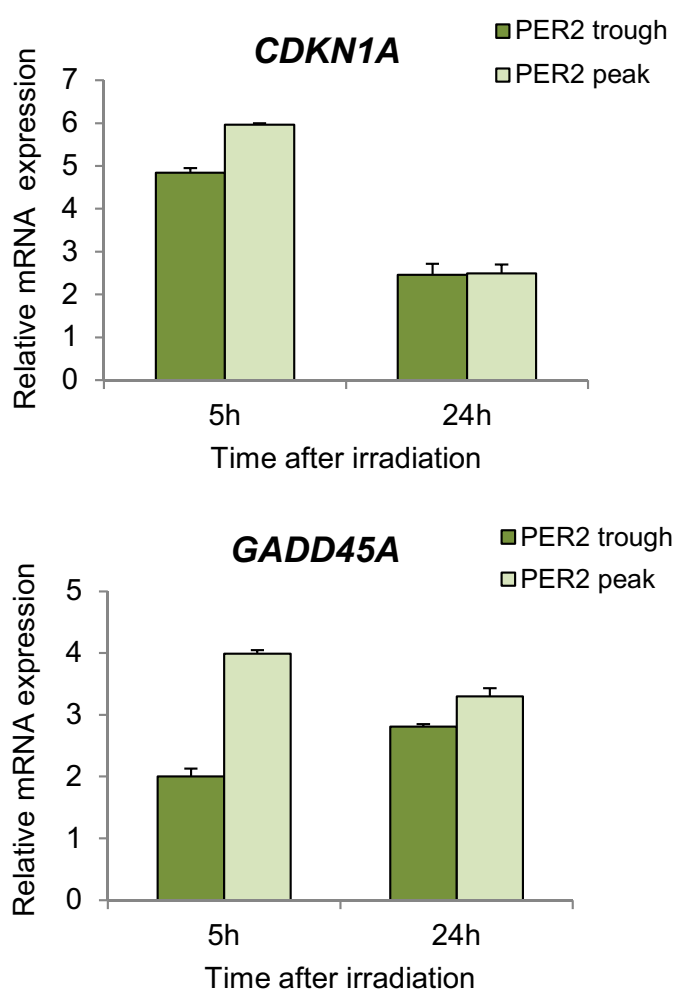

Fig. 7 Expression level of p53-related genes in serum-shocked human fibroblasts CCD-34Lu irradiated with $\gamma$ rays. The relative expression of CDKN1A (p21), GADD45A, and $c-M Y C$ transcripts was measured at 5 and $24 \mathrm{~h}$ after irradiation ( 5 Gy)performed at the

\section{Discussion}

The disruption of circadian rhythmicity or irregular circadian cycles, such as those experienced by nightshift workers in humans or caused by constant exposure to light in rodents, have been associated with higher cancer risk (Anderson et al. 2000; Hansen 2006; Megdal et al. 2005; Sigurdardottir et al. 2012; van den Heiligenberg et al. 1999). Per genes are mutated or deleted in many tumor tissues, and altered PER2 expression is common in human breast cancer (Chen et al. 2005; Winter et al. 2007) and in patients with prostate cancer (Kiss and Ghosh 2016). The PER2 $2^{S 662 G}$ mutation has been found to be responsible for abnormal DNAdamage response (DDR) and increased cancer risk (Gu et al. 2012). Mice deficient in the mPer2 gene were found to be cancer-prone. These mice showed, in fact, a marked increase in tumor development and reduced apoptosis after gamma-irradiation (Fu et al. 2002). Alterations in the expression of critical clock genes have been reported in both breast (Chen et al. 2005; Yang
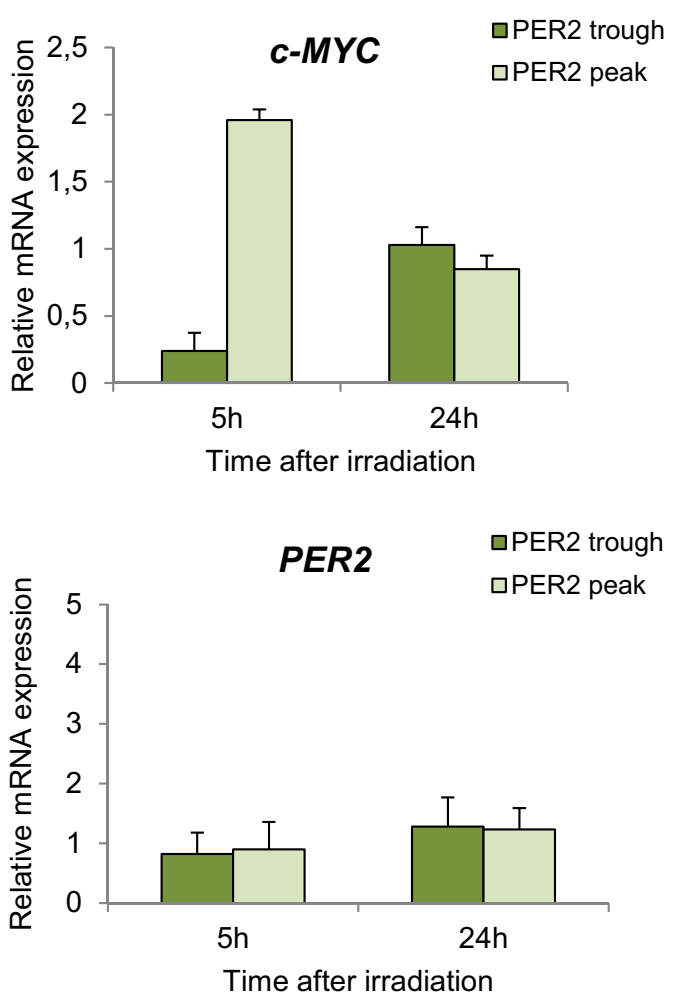

trough and the peak of PER2 protein expression. The relative expression of PER 2 transcript is reported at both irradiation times. Values (mean $\pm \mathrm{SD}$ ) are expressed as fold-change of irradiated vs. non-irradiated control cells of each group

et al. 2009) and gastric cancer (Hu et al. 2014). It has recently become apparent that DNA repair, transcriptional reprogramming, and apoptosis exhibit daily fluctuations, suggesting that the time of exposure to genotoxic stress could affect cell response.

The current study focused on the cellular response to DNA damage that was induced by ionizing radiation (IR) in normal human CCD-34Lu fibroblasts to clarify the relationships between the circadian rhythmicity and the DNA-damage response pathway. Since cell proliferation depends on extracellular mitogen-activated signals, it is temporally controlled by the circadian clock and these interactions may have both physiological and pathological implications. For these reasons, we analyzed normal non-proliferating fibroblasts, in which circadian rhythm was induced by applying a 2-h pulse of horse serum, a method that has been used to synchronize clock gene expression in mammalian cells (Balsalobre et al. 1998; Huang et al. 2009). Here, it was successfully applied to non-proliferating CCD$34 \mathrm{Lu}$ cells, as demonstrated by the time course of 
PER1, PER2, and BMAL1 gene expression and PER2 protein (Fig. 2). The results concord with recent data obtained in quiescent human skin fibroblasts showing the same circadian times of PER2 maximum and minimum expression after dexamethasone pulse (Bee et al. 2015). PER2 is an important component of the circadian system, and its role has been clarified to some extent by several previous studies. Clock gene Per 2 is robustly and rhythmically expressed in almost all mammalian tissues (Albrecht et al. 2007), and under physiological conditions, PER2 oscillates rhythmically showing a peak and a trough that are in anti-phase with the other important clock gene BMAL1. Circadian oscillators are robust also in in vitro cultured fibroblasts which harbor self-sustained and cell-autonomous circadian clocks similar to those operative in SCN neurons (Nagoshi et al. 2004). In our cell system, the knockdown of the PER2 gene affected the normal rhythmic expression of the PER 1 gene, whose level was downregulated, whereas we found no marked alterations in the mRNA expression of BMAL1 in PER2-silenced cells, suggesting that $B M A L 1$ is not subject to PER2 regulation at the transcriptional level in CCD-34Lu cells (Fig. 3). However, since our data are only concentrated on the transcriptional level, further studies on the translational and post-translational levels are needed to investigate the role of PER2 in the clock gene network of human normal fibroblasts.

Similar to those that normally occur during medical or accidental radiation exposure, it has been shown that the $\gamma$-ray doses utilized during the current study elicit a DDR in CCD-34Lu cells (Bee et al. 2013). At the time of exposure to DNA damage, the CCD-34Lu cells were non-proliferating and stimulated after IR to enter the cell cycle to originate colonies. Study results demonstrating that cells irradiated at the trough and not at the peak of PER2 were affected with regard to their clonogenic capacity concord with reports showing increased sensitivity to $\gamma$ radiation in Per 2 mutant mice (Fu et al. 2002) and decreased radio sensitivity in proliferating NIH 3T3 fibroblasts overexpressing mPer2 (Chang et al. 2009). But data regarding clonogenic survival in clock-altered cells exposed to genotoxic stress showed quite a different picture. Overexpression of clock gene Perl in human cancer cell lines led to significant growth reduction following ionizing radiation (Gery et al. 2006), whereas mouse cell lines mutated in clock genes were indistinguishable from wild-type ones in their response to ionizing radiation and other DNA damaging agents
(Gaddameedhi et al. 2012). These discrepancies could be due to the interconnectivity between the circadian clock and the cell cycle as well as to a strict connection between the cell cycle and the malignant phenotype. In parallel experiments carried out in cycling clocksynchronized CCD-34Lu cells, we did not evidence indeed differences in clonogenic survival between cells irradiated at the peak than at the trough of PER2 expression (data not shown).

In addition to cell survival, even DSB repair was affected in non-proliferating CCD-34Lu irradiated at the trough of PER2 protein expression; indeed, a higher number of foci were retained in the nuclei of cells irradiated at the trough with respect to the peak of PER2, indicating a delay in DSB resolution (Fig. 5). Our results are in accordance with recent evidence showing that mouse splenocytes exhibit significant differences in IR-induced DNA damage/repair response during the 24-h light-dark cycle, with faster and more efficient repair activities during the light phase of the day (Palombo et al. 2015) when the Per2 gene expression and PER2 protein levels are higher with respect to nighttime values (Zhao et al. 2015).

We also analyzed TP53 expression levels after irradiation to determine if cells with high and low endogenous levels of PER2 protein respond differently to DNA damage. In normal unstressed cells, the TP53 protein is maintained at low steady-state levels by a turnover that is predominantly regulated by MDM2-mediated ubiquitination and degradation. TP53 is stabilized in response to DNA damage because MDM2's ability to inhibit p53-dependent transactivation is impaired (Shieh et al. 1997), meaning that it is rapidly accumulated. The circadian rhythmicity of the TP53 gene has been observed in various tissues (Soták et al. 2014), while the expression of TP53 protein has been observed to be rhythmic in human oral mucosa (Bjarnason et al. 1999) and in malignant cells although mRNA TP53 levels did not vary (Horiguchi et al. 2013). In the current study, the TP53 gene expression did not show a robust circadian oscillation in non-irradiated cells during the 44-h time course after serum shock (supplementary Fig. 4) nor did it show a strong induction after irradiation (Fig. 6a). Previous studies established a connection between the circadian regulatory system and the DNA-damage response mechanism at the level of Per2-p53 interaction in circadian synchronized human colorectal carcinoma cells (Gotoh et al. 2014, 2015). Very recently, Gotoh et al. (2016) proposed a unifying model for Per2-mediated 
regulation of p53 translocation and signaling. Under physiological conditions, the Per2:p53 interaction represents a mode of controlling the endogenous level of p53, and in cells exposed to genotoxic stimuli, such interaction is functionally relevant for modulating p53-mediated transcriptional response. Both processes are related and mediated by events that control the translocation and availability of p53 via Per2 in each subcellular compartment over the course of the circadian cycle. In our experiments, the TP53 protein was detectable after IR in the nuclei of the cells irradiated at peak PER2 expression but it was slightly detectable in cells irradiated at the trough one (Fig. 6b). To learn more about the role of PER2 expression in TP53 activation, we analyzed phosphorylated TP53(Ser15), since phosphorylation in response to DNA damage is correlated both with the accumulation of total TP53 protein and with TP53's ability to transactivate downstream target genes in wild-type cells (Siliciano et al. 1997). Increased levels of phospho-P53 were detected very early after irradiation in the cells irradiated at the peak but not at the trough PER2 expression (Fig. 6b). At other times after irradiation, phosphorylated TP53 was poorly detectable in all the samples, in accordance with a peak of induction at $3 \mathrm{~h}$ after irradiation followed by degradation UBE4B-mediated of phospho-p53(S15) (Du et al. 2016). Accordingly, circadian-regulated p53related genes CDKN1A, GADD45A, and $c-M Y C$ were more induced at $5 \mathrm{~h}$ after irradiation in cells irradiated at peak than trough PER2 expression(Fig. 7). CDKN1A and $G A D D 45 A$ are known to be radioresponsive genes whose expression level markedly increases following irradiation in human lymphocytes (Amundson et al. 2003; Mognato and Celotti 2005; Badie et al. 2008; Girardi et al. 2012). $c-M Y C$, which is not classified as a radioresponsive gene, is nevertheless induced in human $\mathrm{G}_{0}$ lymphocytes following $\gamma$-irradiation (Girardi et al. 2012). On the basis of these findings, we speculate that DNA-damage response in $\gamma$-irradiated CCD-34Lu cells could depend on the cross-talk between PER2 function and TP53 protein which is relevant for modulating P53-mediated transcriptional response under stress conditions.

\section{Conclusions}

The present study aimed to analyze the DNA-damage response to ionizing radiation in primary human lung fibroblasts when endogenous PER2 level was at its peak or trough of expression, simulating, as far as possible, conditions similar to those occurring under physiological conditions of circadian rythmicity. Taken together, our results show that clonogenic cell survival, DSB repair, and TP53 activation were affected in irradiated cells with low endogenous PER2 protein levels. Although further studies are warranted to elucidate the mechanism/s interconnecting the circadian clock and the DDR pathway, the current findings have provided more information about the DNA-damage response of human normal non-proliferating fibroblasts, reflecting the physiological condition of most cells in the adult organism. The results must nevertheless be interpreted as cell-based in in vitro systems in which the circadian component is limited in animal models.

Acknowledgments This work was supported by the University of Padova (grants 60A06-9009/11; 60A06-3595/12). We gratefully acknowledge Prof. Chiara Romualdi for statistical analyses.

Authors' contributions SC and RS performed the experiments. LB designed and performed the first experiments of serum-shock synchronization. VB irradiated the cells. MM conceived and designed the experiments, analyzed the data, and wrote the paper.

\section{Compliance with ethical standards}

Conflict of interest The authors declare that they have no conflicts of interest.

Open Access This article is distributed under the terms of the Creative Commons Attribution 4.0 International License (http:// creativecommons.org/licenses/by/4.0/), which permits unrestricted use, distribution, and reproduction in any medium, provided you give appropriate credit to the original author(s) and the source, provide a link to the Creative Commons license, and indicate if changes were made.

\section{References}

Albrecht U, Bordon A, Schmutz I, Ripperger J. The multiple facets of Per2. Cold Spring HarbSymp Quant Biol. 2007;72:95-104.

Allen G, Rappe J, Earnest DJ, Cassone VM. Oscillating on borrowed time: diffusible signals from immortalized suprachiasmatic nucleus cells regulate circadian rhythmicity in cultured fibroblasts. J Neurosci. 2001;21(20):7937-43.

Amundson SA, Lee RA, Koch-Paiz CA, Bittner ML, Meltzer P, Trent JM, Fornace AJ Jr. Differential responses of stress genes to low dose-rate gamma irradiation. Mol Cancer Res. 2003;1(6):445-52.

Anderson LE, Morris JE, Sasser LB, Stevens RG. Effect of constant light on DMBA mammary tumorigenesis in rats. Cancer Lett. 2000;148(2):121-6. 
Badie C, Dziwura S, Raffy C, Tsigani T, Alsbeih G, Moody J, Finnon P, Levine E, Scott D, Bouffler S. Aberrant CDKN1A transcriptional response associates with abnormal sensitivity to radiation treatment. Br J Cancer. 2008;98(11):1845-51.

Balsalobre A, Damiola F, Schibler U. A serum shock induces circadian gene expression in mammalian tissue culture cells. Cell. 1998;93(6):929-37.

Bee L, Fabris S, Cherubini R, Mognato M, Celotti L. The efficiency of homologous recombination and non-homologous end joining systems in repairing double-strand breaks during cell cycle progression. PLoS One. 2013;8(7):e69061.

Bee L, Marini S, Pontarin G, Ferraro P, Costa R, Albrecht U, Celotti L. Nucleotide excision repair efficiency in quiescent human fibroblasts is modulated by circadian clock. Nucleic Acids Res. 2015;43(4):2126-37.

Bjarnason GA, Jordan RC, Sothern RB. Circadian variation in the expression of cell-cycle proteins in human oral epithelium. Am J Pathol. 1999;154:613-22.

Canaple L, Kakizawa T, Laudet V. The days and nights of cancer cells. Cancer Res. 2003;63:7545-52.

Canova S, Fiorasi F, Mognato M, Grifalconi M, Reddi E, Russo A, Celotti L. "Modeled microgravity" affects cell response to ionizing radiation and increases genomic damage. Radiat Res. 2005;163(2):191-9.

Celeste A, Fernandez-Capetillo O, Kruhlak MJ, Pilch DR, Staudt DW, Lee A, Bonner RF, Bonner WM, Nussenzweig A. Histone H2AX phosphorylation is dispensable for the initial recognition of DNA breaks. Nat Cell Biol. 2003;5:675-9.

Ceriani MF, Darlington TK, Staknis D, Más P, Petti AA, Weitz CJ, Kay SA. Light-dependent sequestration of TIMELESS by CRYPTOCHROME. Science. 1999;285(5427):553-6.

Chang L, Liu YY, Zhu B, Li Y, Hua H, Wang YH, Zhang J, Jiang Z, Wang ZR. High expression of the circadian gene mPer2 diminishes the radiosensitivity of NIH3T3 cells. Braz J Med Biol Res. 2009;42(10):882-91.

Chen ST, Choo KB, Hou MF, Yeh KT, Kuo SJ, Chang JG. Deregulated expression of the PER1, PER2 and PER3 genes in breast cancers. Carcinogenesis. 2005;26(7):1241-6.

Du C, Wu H, Leng RP. UBE4B targets phosphorylatedp53 at serines 15 and 392 for degradation. Oncotarget. 2016;7(3): 2823-36.

Fede C, Selvestrel F, Compagnin C, Mognato M, Mancin F, Reddi E, Celotti L. The toxicity outcome of silica nanoparticles (Ludox $®$ ) is influenced by testing techniques and treatment modalities. Anal Bioanal Chem. 2012;404(6-7):1789-802.

Flynn-Evans EE, Mucci L, Stevens RG, Lockley SW. Shiftwork and prostate-specific antigen in the National Health and Nutrition Examination Survey. J Natl Cancer Inst. 2013;105:1292-7.

Franzolin E, Pontarin G, Rampazzo C, Miazzi C, Ferraro P, Palumbo E, Reichard P, Bianchi V. The deoxynucleotidetriphosphohydrolase SAMHD1 is a major regulator of DNA precursor pools in mammalian cells. Proc Natl Acad Sci U S A. 2013;110(35):14272-7.

Fu L, Pelicano H, Liu J, Huang P, Lee C. The circadian gene Period2 plays an important role in tumor suppression and DNA damage response in vivo. Cell. 2002;111(1):41-50. Erratum in: Cell 2002; 111(7):1055

Gaddameedhi S, Selby CP, Kaufmann WK, Smart RC, Sancar A. Control of skin cancer by the circadian rhythm. ProcNatlAcadSci U S A. 2011;108(46):18790-5.
Gaddameedhi S, Reardon JT, Ye R, Ozturk N, Sancar A. Effect of circadian clock mutations on DNA damage response in mammalian cells. Cell Cycle. 2012;11(18):3481-91.

Gallego M, Virshup DM. Post-translational modifications regulate the ticking of the circadian clock. Nat Rev Mol Cell Biol. 2007;8(2):139-48.

Gery S, Komatsu N, Baldjyan L, Yu A, Koo D, Koeffler HP. The circadian gene perl plays an important role in cell growth and DNA damage control in human cancer cells. Mol Cell. 2006;22:375-82.

Girardi C, de Pittà C, Casara S, Sales G, Lanfranchi G, Celotti L, Mognato M. Analysis of miRNA and mRNA expression profiles highlights alterations in ionizing radiation response of human lymphocytes under modeled microgravity. PLoS One. 2012;7:e31293.

Gotoh T, Vila-Caballer M, Santos CS, Liu J, Yang J, Finkielstein CV. The circadian factor Period 2 modulates p53 stability and transcriptional activity in unstressed cells. MolBiol Cell. 2014;25(19):3081-93.

Gotoh T, Vila-Caballer M, Liu J, Schiffhauer S, Finkielstein CV. Association of the circadian factor Period 2 to 553 influences p53's function in DNA-damage signaling. MolBiol Cell. 2015;26(2):359-72.

Gotoh T, Kim JK, Liu J, Vila-Caballer M, Stauffer PE, Tyson JJ, Finkielstein CV. Association of the circadian factor Period 2 to 553 influences p53's function in DNA-damage signaling. Proc Natl Acad Sci U S A. 2016;113(47):13516-21.

Gréchez-Cassiau A, Rayet B, Guillaumond F, Teboul M, Delaunay F. The circadian clock component BMAL1 is a critical regulator of $\mathrm{p} 21 \mathrm{WAF} 1 / \mathrm{CIP} 1$ expression and hepatocyte proliferation. J Biol Chem. 2008;283(8):4535-42.

Gu X, Xing L, Shi G, Liu Z, Wang X, Qu Z, Wu X, Dong Z, Gao X, Liu G, Yang L, Xu Y. The circadian mutation PER2(S662G) is linked to cell cycle progression and tumorigenesis. Cell Death Differ. 2012;19(3):397-405.

Hansen J. Risk of breast cancer after night- and shift work: current evidence and ongoing studies in Denmark. Cancer Causes Control. 2006;17(4):531-7.

Horiguchi M, Koyanagi S, Hamdan AM, Kakimoto K, Matsunaga N, Yamashita C, Ohdo S. Rhythmic control of the ARFMDM2 pathway by ATF4 underlies circadian accumulation of p53 in malignant cells. Cancer Res. 2013;73(8):2639-49.

$\mathrm{Hu}$ ML, Yeh KT, Lin PM, Hsu CM, Hsiao HH, Liu YC, Lin HY, Lin SF, Yang MY. Deregulated expression of circadian clock genes in gastric cancer. BMC Gastroenterol. 2014;14:67.

Huang TS, Grodeland G, Sleire L, Wang MY, Kvalheim G, Laerum OD. Induction of circadian rhythm in cultured human mesenchymal stem cells by serum shock and cAMP analogs in vitro. Chronobiol Int. 2009;26(2):242-57.

Kang TH, Reardon JT, Kemp M, Sancar A. Circadian oscillation of nucleotide excision repair in mammalian brain. ProcNatlAcadSci U S A. 2009;106(8):2864-7.

Kang TH, Lindsey-Boltz LA, Reardon JT, Sancar A. Circadian control of XPA and excision repair of cisplatin-DNA damage by cryptochrome and HERC2 ubiquitin ligase. ProcNatlAcadSci U S A. 2010;107(11):4890-5.

Karakostis K, Ponnuswamy A, Fusée LT, Bailly X, Laguerre L, Worall E, Vojtesek B, Nylander K, Fåhraeus R. p53 mRNA and p53 Protein Structures Have Evolved Independently to Interact with MDM2. Mol Biol Evol. 2016;pii:msw012. 
Kiss Z, Ghosh PM. WOMEN IN CANCER THEMATIC REVIEW: circadian rhythmicity and the influence of 'clock' genes on prostate cancer. EndocrRelat Cancer. 2016;23(11): T123-34.

Knutsson A, Alfredsson L, Karlsson B, Akerstedt T, Fransson EI, Westerholm P, Westerlund H. Breast cancer among shiftworkers: results of the WOLF longitudinal cohort study. Scand J Work Environ Health. 2013;39(2):170-7.

Kowalska E, Ripperger JA, Hoegger DC, Bruegger P, Buch T, Birchler T, Mueller A, Albrecht U, Contaldo C, Brown SA. NONO couples the circadian clock to the cell cycle. ProcNatlAcadSci U S A. 2013;110(5):1592-9.

Koyanagi S, Hamdan AM, Horiguchi M, Kusunose N, Okamoto A, Matsunaga N, Ohdo S. cAMP-response element (CRE)mediated transcription by activating transcription factor- 4 (ATF4) is essential for circadian expression of the Period2 gene. J Biol Chem. 2011;286(37):32416-23.

Kwon I, Choe HK, Son GH, Kim K. Mammalian molecular clocks. ExpNeurobiol. 2011;20(1):18-28.

Lee CC. The circadian clock and tumor suppression by mammalian period genes. Methods Enzymol. 2005;393:852-61.

Livak KJ, Schmittgen TD. Analysis of relative gene expression data using real-time quantitative PCR and the 2(-Delta Delta C(T)) method. Methods. 2001;25:402-8.

Manzella N, Bracci M, Strafella E, Staffolani S, Ciarapica V, Copertaro A, Rapisarda V, Ledda C, Amati M, Valentino M, Tomasetti M, Stevens RG, Santarelli L. Circadian modulation of 8-oxoguanine DNA damage repair. Sci Rep. 2015;5:13752.

Matsuo T, Yamaguchi S, Mitsui S, Emi A, Shimoda F, Okamura H. Control mechanism of the circadian clock for timing of cell division in vivo. Science. 2003;302(5643):255-9.

Megdal SP, Kroenke CH, Laden F, Pukkala E, Schernhammer ES. Night work and breast cancer risk: a systematic review and meta-analysis. Eur J Cancer. 2005;41(13):2023-32.

Miki T, Matsumoto T, Zhao Z, Lee CC. p53 regulates Period2 expression and the circadian clock. Nat Commun. 2013;4:2444.

Mognato M, Celotti L. Modeled microgravity affects cell survival and HPRT mutant frequency, but not the expression of DNA repair genes in human lymphocytes irradiated with ionising radiation. Mutat Res/Mutat Res Fundam Mol Mech Mutagen 2005;578(1-2):417-429.

Nagoshi E, Saini C, Bauer C, Laroche T, Naef F, Schibler U. Circadian gene expression in individual fibroblasts: cellautonomous and self-sustained oscillators pass time to daughter cells. Cell. 2004;119(5):693-705.

Palombo P, Moreno-Villanueva M, Mangerich A. Day and night variations in the repair of ionizing-radiation-induced DNA damage in mouse splenocytes. DNA Repair (Amst). 2015;28:37-47.

Rappold I, Iwabuchi K, Date T, Chen J. Tumor suppressor p53 binding protein 1 (53BP1) is involved in DNA damagesignaling pathways. J Cell Biol. 2001;153:613-20.

Roenneberg T, Merrow M. Entrainment of the human circadian clock. Cold Spring Harb Symp Quant Biol. 2007;72:293-9.

Savvidis C, Koutsilieris M. Circadian rhythm disruption in cancer biology. Mol Med. 2012;18:1249-60.

Schultz LB, Chehab NH, Malikzay A, Halazonetis TD. p53 binding protein $1(53 \mathrm{BP} 1)$ is an early participant in the cellular response to DNA double-strand breaks. J Cell Biol. 2000;151:1381-90.

Sharma A, Singh K, Almasan A. Histone H2AX phosphorylation: a marker for DNA damage. Methods Mol Biol. 2012;920: 613-26.

Shieh SY, Ikeda M, Taya Y, Prives C. DNA damage-induced phosphorylation of p53 alleviates inhibition by MDM2. Cell. 1997;91:325-34.

Sigurdardottir LG, Valdimarsdottir UA, Fall K, Rider JR, Lockley SW, Schernhammer E, Mucci LA. Circadian disruption, sleep loss, and prostate cancer risk: a systematic review of epidemiologic studies. Cancer Epidemiol Biomark Prev. 2012;21(7):1002-11.

Siliciano JD, Canman CE, Taya Y, Sakaguchi K, Appella E, Kastan MB. DNA damage induces phosphorylation of the amino terminus of p53. Genes Dev. 1997;11(24):3471-81.

Soták M, Sumová A, Pácha J. Cross-talk between the circadian clock and the cell cycle in cancer. Ann Med. 2014;46(4):221-32.

Stevens RG. Circadian disruption and breast cancer: from melatonin to clock genes. Epidemiology. 2005;16(2):254-8.

Straif K, Baan R, Grosse Y, Secretan B, El Ghissassi F, Bouvard V, et al. Carcinogenicity of shift -work, painting, and fire-fighting. Lancet Oncol. 2007;8:1065-6.

Tauber E, Kyriacou CP. Molecular evolution and population genetics of circadian clock genes. Methods Enzymol. 2005;393:797-817.

Toh KL, Jones CR, He Y, Eide EJ, Hinz WA, Virshup DM, Ptácek $\mathrm{LJ}, \mathrm{Fu} \mathrm{YH}$. An hPer2 phosphorylation site mutation in familial advanced sleep phase syndrome. Science. 2001;291(5506): 1040-3.

van den Heiligenberg S, Deprés-Brummer P, Barbason $\mathrm{H}$, Claustrat B, Reynes M, Lévi F. The tumor promoting effect of constant light exposure on diethylnitrosamine-induced hepatocarcinogenesis in rats. Life Sci. 1999;64(26):2523-34.

Whitmore D, Foulkes NS, Sassone-Corsi P. Light acts directly on organs and cells in culture to set the vertebrate circadian clock. Nature. 2000;404(6773):87-91.

Winter SL, Bosnoyan-Collins L, Pinnaduwage D, Andrulis IL. Expression of the circadian clock genes Per1 and Per2 in sporadic and familial breast tumors. Neoplasia. 2007;9(10): 797-800.

Wood PA, Du-Quiton J, You S, Hrushesky WJ. Circadian clock coordinates cancer cell cycle progression, thymidylate synthase, and 5-fluorouracil therapeutic index. Mol Cancer Ther. 2006;5(8):2023-33. Erratum in: Mol Cancer Ther. 2006; Dec;5(12):3312

$\mathrm{Xu}$ Y, Padiath QS, Shapiro RE, Jones CR, Wu SC, Saigoh N, Saigoh K, Ptácek LJ, Fu YH. Functional consequences of a CKIdelta mutation causing familial advanced sleep phase syndrome. Nature. 2005;434(7033):640-4.

Yang X, Wood PA, Oh EY, Du-Quiton J, Ansell CM, Hrushesky WJ. Down regulation of circadian clock gene Period 2 accelerates breast cancer growth by altering its daily growth rhythm. Breast Cancer Res Treat. 2009;117(2):423-31.

Zhao Z, Xu H, Liu Y, Mu L, Xiao J, Zhao H. Diurnal expression of the Per2 gene and protein in the lateral habenular nucleus. Int J Mol Sci. 2015;16(8):16740-9. 